BIOMEDICAL AND BIOSOCIAL ANTHROPOLOGY
$\begin{gathered}\text { Official Journal of the International Academy } \\ \text { of Integrative Anthropology } \\ \text { journal homepage: http://bba-journal.com }\end{gathered}$

\title{
Correlations of indices of personality traits with indexes of finger and palmar dermatoglyphics of practically healthy Ukrainian men
}

Gunas V. I.

National Pirogov Memorial Medical University, Vinnytsya, Ukraine

\section{ARTICLE INFO}

Received: 21 December 2018

Accepted: 18 January 2019

UDC: $572.524 .12: 159.923$

\section{CORRESPONDING AUTHOR}

e-mail: freekozak1@gmail.com Gunas V. I.
The search for new psychodermatoglyphic correlations will greatly increase the possibilities of this method and will accelerate the introduction of scientific developments into the daily practice of clinicians, criminologists, police and other specialties. The purpose of the work is to establish the peculiarities of the relationship between the indexes of the finger and palmar dermatoglyphics and the characteristics of the personality traits of practically healthy Ukrainian men. From the data bank of the materials of the research center of National Pirogov Memorial Medical University, Vinnytsya were taken the primary questionnaires of indicators of personality characteristics and dermatoglyphic indicators of 92 practically healthy men residents of Podillia region of Ukraine in the third generation. Processing of indicators of finger and palmar dermatoglyphics was performed according to the method of Cummins $\mathrm{H}$. and Midlo Ch. (1961) in the statement by Gladkova T. D. (1966). To assess the characteristics of personality characteristics we determined properties of temperament (according to Eysenck), anxiety (according to Spielberger), accentuated personality traits (according to Shmishek), motivational orientation of the personality (according to Rotter), as well as features of the emotional organization of personality, aggressiveness, level of personality manifestations (according to Luscher). Correlation analysis was performed in the "Statistica 6.1" license package using Pearson statistics. It has been established that in the majority of cases, indicators of personality traits and dermatoglyphic indices of almost healthy men show single direct and inverse, mostly weak forces $(r=0.21-0.29$ and $r=-0.21--0.28$, respectively) correlations. The multiple nature of such correlations is established only between the Luscher gray color index and the left hand I, III and IV fingers and the left hand I and II fingers ridge count, the total ridge count of both hands, the total ridge count and the left hand delta index $(r=-0.23$ -0.28) and between most indicators by Rotter subjective scale and the presence of a pattern on the thenar of the corresponding palm (on the right hand $-r=0.31-0.37$ and on the left hand $-r=0.22-0.29$ ). The results of quantitative analysis of significant correlations showed that between the indexes of the finger dermatoglyphics and the indicators of personality traits according to Eysenck and Luscher, most relationships are inverse, and with Spielberger, Shmishek and Rotter - direct; between the indexes of the palmar dermatoglyphics and the indicators of personality traits according to Spielberger and Luscher, most reliable relationships are inverse, and with the indicators according to Eysenck, Shmishek and Rotter - direct. The results of the correlation analysis allowed us to determine the most significant relationships between the indexes of the finger and palmar dermatoglyphics and the characteristics of the personality traits of practically healthy Ukrainian men.

Keywords: dermatoglyphic indices, indicators of personality traits, practically healthy men, correlations.

\section{Introduction}

Psychodermatoglyphics has been widely used in recent decades to identify a predisposition to many mental illnesses and to create a psychological portrait of criminals, drug addicts or other similar groups of the population [3, 11, 12].

S. N. Akbarova and G. A. Azimova [2] conducted studies 
to identify dermatoglyphical and psychological features of drug users. Among the psychic features such qualities as lack of kindness, inability to determine one's own benefit, lack of desire to engage in dialogue, poor tolerance of difficulties, etc. are noted. Specific dermatological and psychological markers were also identified in the analysis of fingerprints, namely, the predominance of the arch type on the first finger of the right hand, the first, third and fifth fingers of the left hand, and the whorls on the thenar of both the left and right palms.

O. M. Zoroastrov, A. N. Chistykin, and I. S. Efremov [22] investigated the features of a skin pattern in 231 persons who were in prison for murder or grievous bodily harm. Specific features were found that are characteristic of this category of persons, such as an increase in the number of whorls on the fourth finger of the right hand, the second and third fingers of the left hand, and a decrease in the number of ulnar loops on the third finger of the left hand. There was also an increase in the ridge count on the fourth finger of the right hand and the fifth and fourth fingers of the left hand. The findings will help create risk groups, among which preventive measures can be taken to reduce the number of serious crimes. The same group of authors [7] revealed the features of skin pattern in persons convicted of rape, namely, the reduction of the frequency of ulnar loops on the second finger of the right hand, the increase in the number of whorls and the ridge count on the fourth finger of the right hand, the reduction of the ridge count of the $c-d$ line on the right hand, increase in the number of whorls on the second-fifth fingers of the left hand, decrease in the frequency of ulnar loops on the first and fourth fingers of the left hand, decrease in the number of radial loops on the second finger of the left hand, increasing the ridge count on the third and fourth fingers of the left hand, reducing of ridge count $a-b$ on the left hand. In this way, it is possible to identify potential risk groups and preventive measures.

It has been found that specific features of a person's skin pattern can be used to detect a tendency for antisocial behavior related to social isolation, depressive mentality, lack of emotions and negativity [21].

I. Oron [16] aimed to identify specific dermatoglyphic markers in persons who were intentionally injured. A total of 160 dermatoglyphs were investigated during the study for the first time to intentionally injure a body in age of 13-16 years. The results of the analysis of the data obtained revealed 16 dermatoglyphic features that can be further used to identify risk groups.

The purpose of the work is to establish the peculiarities of the relationship between the indexes of the finger and palmar dermatoglyphics and the characteristics of the personality traits of practically healthy Ukrainian men.

\section{Materials and methods}

From the data bank of the materials of the research center of National Pirogov Memorial Medical University, Vinnytsya taken the primary questionnaires of personality characteristics and indexes of finger and palmar dematoglyphics of 92 practically healthy men aged from 22 to 35 years, residents of Podillia region of Ukraine in the third generation (representatives of Vinnytsia, Khmelnitsky, part of Ternopil and Zhytomyr regions).

Processing of indicators of finger and palmar dermatoglyphics was performed according to the method of Cummins $\mathrm{H}$. and Midlo $\mathrm{Ch}$. [5] in the statement by Gladkova T. D. [9].

To evaluate the characteristics of personality characteristics based on the use of personal questionnaires and test methods were identified a number of properties of temperament (according to Eysenck), anxiety (according to Spielberger), accentuated personality traits (according to Shmishek), motivational orientation of the personality (according to Rotter), as well as the peculiarities of psychoemotional organization of personality, aggression, the level of distribution of asthenic and depressive personality manifestations (by the Luscher color test) $[6,8,10,13,15$, 17, 18, 20].

Correlations were estimated using a "Statistica 6.1" license package using Pearson statistics.

\section{Results}

The following significant correlations were found between personality traits and finger dermatoglyphics of healthy men: the Eysenck neuroticism scale has a mean feedback force $(r=-0.31)$ correlation with the pattern type on the IV finger of the right hand and the mean direct force ( $r=$ 0.30 ) correlation with the pattern type on the III finger of the left hand; Eysenck indiscretion score - only weak force feedback ( $r=-0.27$ ) correlation with pattern type on the second finger of the right hand; Spielberger's personal anxiety score - average direct link strength correlation $(r=0.33)$ with the pattern on the III left hand finger pattern and weak direct link strength correlation $(r=0.21)$ with the pattern on the left $V$ finger pattern; an indicator of accentuation of the character of the hyperthymic type according to Shmishek - only a weak force of a direct correlation ( $r=0.21)$ with a delta index of the left hand; an indicator of accentuation of the character of the sticking type according to Shmishek - only weak force feedback $(r=-0.26)$ correlation with the pattern type on the IV fingers of the right hand; an indicator of accentuation of the character of the emotional type according to Shmishek only a weak force direct correlation $(r=0.23)$ with the pattern type on the $\mathrm{V}$ finger of the left hand; cyclothymic type accentuation index by Shmishek - only weak force direct correlation ( $r=0.22)$ with pattern type on the III finger of the left hand; an indicator of accentuation of the character of the demonstrative type according to Shmishek - only a weak force direct correlation $(r=0.23)$ with the ridge count $V$ of the finger of the right hand; an indicator of accentuation of the nature of the exciting type by Shmishek - weak force feedback $(r=-0.22$ and -0.23 ) correlation with a ridge count of the III finger of the right and left hands; an indicator of the accentuation of the character of the exalted type by 
Shmishek - average direct link strength $(r=0.35)$ correlation with pattern type on the III finger of the left hand and weak direct link strength $(r=0.24)$ correlation with pattern type on the $\mathrm{V}$ finger of the right hand; an indicator of the level of subjective control in the field of family relations according to Rotter - only a weak force direct correlation $(r=0.21)$ with the pattern type on the II finger of the right hand; blue color by Luscher - only weak force feedback $(r=-0.21)$ correlation with pattern type on the third finger of the right hand; blue-green color by Luscher - straight weak correlation ( $r=0.23-0.27$ ) lines with pattern type on the III finger of the right hand, a ridge count of the second finger of the left hand and delta index of the left hand; brown color by Luscher - only weak force direct correlation $(r=0.26)$ with the type of pattern on the I finger of the right hand; black color by Luscher - only weak force direct correlation $(r=0.23)$ with pattern type on the third finger of the right hand; gray color by Luscher - medium feedback strength $(r=-0.39)$ correlation with pattern type on the left finger of the left hand, as well as reliable feedback of weak correlation force $(r=-0.23-0.28)$ with a ridge count and the right finger and left hand, a left-hand ridge count of II finger, a right-hand ridge count of III finger, a right-hand ridge count of IV finger, a left-hand delta index, a summary rightleft hand, and a total ridge count.

The following significant correlations were found between personality traits indices and palmar dermatoglyphics of practically healthy men: the Eysenck extraversion-introversion score has a weak direct link strength $(r=0.28)$ correlation with the right-hand angle dat value and a low direct link strength $(r=0.23)$ correlation with the presence of a pattern in the I inter-finger gap of the right hand; Eysenck neuroticism score - weak force direct correlation ( $r=0.24$ in both cases) with a frequency of carpal axial tri-radii of the right and left hand, as well as reliable weak force feedback $(r=-0.24)$ correlation with an intermediate frequency axial tri-radii of the left hand; Eysenck indiscretion index - weak force feedback $(r=-0.22$ in both cases) correlation with the magnitude of the angle atd and the length of the line ad of the right hand and weak force of the direct correlation $(r=0.22)$ with the frequency of the central axial tri-radii of the right hand; Spielberger situational (reactive) anxiety index - reverse medium and low correlation forces ( $r=-0.34$ and $r=-0.25$ ) with left and right hands atb angles; Spielberger's personal anxiety score - inverse of weak correlation force ( $r=-0.22$ in both cases) with the length of the ct line of the left hand and the magnitude of the dat angle of the right hand, as well as the weak direct correlation force $(r=0.23)$ with the frequency of carpal axial tri-radii of the right hand and weak force feedback $(r=-0.24)$ correlation with the presence of a pattern on the hypothenar of the right hand; the indicator of the accentuation of the character of the hyperthymic type according to Shmishek - inverse of medium and weak correlation force $(r=-0.30$ and $r=-0.23$ and -0.28 ) with the ridge count of the line $a-b$ and the length of the line ad of the right hand and the ridge count of the line $c-d$ of the left hand, as well as weak force feedbacks ( $r=$
$-0.24--0.28)$ correlation with the presence of a pattern in the I interdigital gap of the right and left hands and with the presence of a pattern on the thenar of the left hand; the indicator of accentuation of the character of the sticking type according to Shmishek - straight weak correlation forces $(r=0.25$ in both cases) with magnitude btc of the right and left hand, as well as weak direct correlation forces $(r=0.24$ and $r=0.26$ ) with frequency any combination of right and left hand tri-radii; an indicator of accentuation of the character of the emotional type according to Shmishek - weak force feedback $(r=-0.26)$ correlation with ridge count of the line $c-d$ of the right hand and weak force direct correlation $(r=0.22)$ with the presence of a pattern on the hypotenuar of the left hand;

an indicator of the accentuation of the character of the pedantic type according to Shmishek - average direct correlation strength $(r=0.32)$ with the presence of a pattern in the III inter-finger gap of the left hand and weak direct correlation strength $(r=0.22)$ with the frequency of the intermediate axial tri-radii of the left hand; cyclothymic accentuation rate by Shmishek type - direct medium and weak correlation forces $(r=0.30$ and $r=0.24-0.26)$ with the ridge count of the $b-c$ line of the right and left hand, the ridge count of the line $a-b$ of the right hand and the angle btc of the left hand, as well as weak feedback force $(r=-0.25)$ correlation with the presence of a pattern on the hypotenuor of the right hand; indicator of accentuation of the character of the demonstrative type according to Shmishek - weak force feedback ( $r=-0.28)$ correlation with a ridge count of line $c-d$ of the left hand, weak force feedbacks $(r=-0.23$ and $r=-0.24)$ correlation with frequency of any combination of right-hand tri-radii and with the frequency of the left axial central axial triradii, as well as the reliable weak force of the direct correlation $(r=0.23)$ with the frequency of the left-hand carpal axial triradii; an indicator of the accentuation of the character of the exalted type according to Shmishek - weak force of direct correlation $(r=0.22)$ with magnitude of angle atb of the left hand, weak force feedback $(r=-0.27$ and $r=-0.28)$ correlation with frequency of intermediate axial tri-radii of right and left hand, as well as reliable weak forces of direct correlation $(r=0.27-0.28)$ with the index value of the main palmar lines of the left hand and with the frequency of the carpal axial triradii of the right and left hand; the indicator of the scale of the general internality of the level of subjective control over Rotter - weak force feedback $(r=-0.22)$ correlation with the magnitude of the angle ctd of the left hand, as well as medium and weak force direct correlation $(r=0.37$ and $r=0.28)$ with the presence of a pattern on the thenar of the right and left hand and a weak force, a direct correlation $(r=0.22)$ with the presence of a pattern in the I inter-finger gap of the right hand; an indicator of the level of subjective control in the field of Rotter's achievements - only a reliable weak force of direct correlation $(r=0.27)$ with the presence of a pattern on the thenar of the right hand;

indicator of the level of subjective control in the field of failures according to Rotter - weak force direct correlation $(r=0.23)$ with the length of the line ct of the right hand, as well 
as medium and weak force direct correlation ( $r=0.35$ and $r=0.29$ ) with the presence of a pattern on the thenar of the right and left hand, weak direct force $(r=0.25)$ correlation with the presence of the pattern in the IV inter-finger gap of the left hand and weak force feedback ( $r=-0.24)$ correlation with the presence of the pattern in the III inter-finger gap of the left hand; indicator of the level of subjective control in the field of family relations according to Rotter - weak force feedback $(r=-0.22)$ correlation with the magnitude of the angle atb of the right hand, as well as medium and weak force direct correlation ( $r=0.37$ and $r=0.25$ ) with the presence of a pattern on the thenar of the right and left hand; indicator of the level of subjective control in the field of interpersonal relations according to Rotter - weak force feedbacks ( $r=-0.24$ and $r=-$ 0.26 ) correlation with the ridge count of the line $c-d$ and the magnitude of the ctd angle of the left hand, medium and weak force direct correlation ( $r=0.31$ and $r=0.28)$ with the presence of a pattern on the thenar of the right and left hand, weak force direct correlation ( $r=0.28$ and $r=0.25)$ with the presence of a pattern in the I inter-finger gap of the right hand and IV inter-finger gap of the left hand, as well as the weak force feedback $(r=-0.25)$ correlation with the presence of a pattern in the III between the left gap of the left hand; the subjective level of subjective control in the field of health and illness according to Rotter - only reliable weak force direct correlation $(r=0.22)$ with the presence of a pattern on the thenar of the left hand; blue color by Luscher - only reliable weak force direct correlation $(r=0.22)$ with the frequency of any combination of tri-radii right hand; blue-green color by Luscher - inverse of weak correlation force $(r=-0.22--0.26)$ with line length ct and dat angle value of right and left hand; orange-red color by Luscher - weak force feedback ( $r=-0.23$ - -0.28) correlation with the frequency of the central axial triradii of the right and left hand and with the presence of a pattern on the thenar of the right hand; light yellow color by Luscher - weak force feedback ( $r=-0.25$ and $r=-0.28$ ) correlation with the frequency of the central axial tri-radii and the presence of a pattern in the second inter-finger gap of the left hand and weak force direct correlation ( $r=0.22)$ with the presence of a pattern in the I inter-finger gap of the right hand; violet color by Luscher - reliable weak force feedback $(r=-0.24)$ correlation with the magnitude of the ctd angle of the right hand and weak force feedback $(r=-0.24)$ correlation with the index value of the main palmar lines of the right hand.

\section{Discussion}

According to a number of studies it is known that specific dermatoglyphic signs are diagnostic markers of the mental state of a person $[1,4,14,19]$. Therefore, the search for new psychodermatoglyphic correlations will greatly increase the possibilities of this method and will accelerate the introduction of scientific developments into the daily practice of clinicians, criminologists, bodies of inquiry and other specialties.

In the analysis of reliable correlations of indices of personality characteristics with dermatoglyphic indices of practically healthy men of Podillia region of Ukraine, in most cases single and inverse, mostly weak correlations strengths are established. Multiple nature of the reliable correlations is established only: mainly weak force inverse correlation $(r=-0.23--0.28)$ of the gray color by Luscher and the indexes of the ridge count I, III and IV fingers of the right hand and I and II fingers of the left hand, summary ridge count of the fingers of both hands, the total ridge count and the deltaic index of the left hand; on the right hand, mainly medium strength direct correlation ( $r=0.31-0.37)$; and on the left hand weak strength direct correlation $(r=0.22-0.29)$ between most indicators of the Rotter subjective scale and the presence of a pattern on the thenar of the corresponding palm.

Quantitative analysis of significant correlations of personality characteristics with dermatoglyphic indices of healthy men showed the following distribution:

extraversion-introversion, neuroticism, and sincerity indicators according to Eysenck - with indexes of finger dermatoglyphics $(5.56 \%$ of the total number of these indicators on the right hand, $2.78 \%$ of the average force of the inverse and $2.78 \%$ of the weak force of the inverse; on the left hand $1-1.39 \%$, medium straight); with indexes of palmar dermatoglyphics (on the right hand $6-9.52 \%$ of the total number of these indicators, of which $6.35 \%$ of the weak force of the direct and $3.17 \%$ of the weak force of the opposite; on the left hand $2-3.18 \%$, of which $1.59 \%$ of the weak force of the direct and $1.59 \%$ weak strength of the inverse);

indicators of situational (reactive) and personal anxiety according to Spielberger - with indexes of finger dermatoglyphics (on the left hand $2-8.34 \%$ of the total amount of these indicators, of which $4.17 \%$ average strength of straight and $4.17 \%$ weak strength of straight); with indexes of palmar dermatoglyphics (on the right hand $4-9.52 \%$ of the total number of these indicators, of which $2.38 \%$ of the weak force of the direct and $7.14 \%$ of the weak force of the opposite; on the left hand $2-4.76 \%$ of the total amount of these indicators, of which $2.38 \%$ of the average reverse force and $2.38 \%$ weak reverse force);

indices of accentuation of the character of hypertensive, stuck, emotional, pedantic, anxious, cyclothymic, demonstrative, excitable, dysthymic and exalted types according to Shmishek - with indexes of finger dermatoglyphics (on the right hand $4-3.34 \%$ of total, straight and $1.67 \%$ of weak force of the inverse; on the left hand 5 $4.16 \%$ of the total number of these indicators, of which 0.83 $\%$ of the average strength of the straight, $2.50 \%$ of the weak force of the straight and $0.83 \%$ of the weak force of the inverse); with indexes of palmar dermatoglyphics (on the right hand $12-5.72 \%$ of the total number of these indicators, of which $2.38 \%$ of the weak force of the direct, $0.48 \%$ of the average force of the reverse and $2.86 \%$ of the weak force of the reverse; on the left hand $17-8.10 \%$ of the total amount of these indicators, of which $0.95 \%$ of the average force of the straight, $4.29 \%$ of the weak force of the straight and $2.86 \%$ of the weak force of the reverse); 
indicators of the scale of general internality of the level of subjective control, subjective control in the fields of achievements, failures, family relations, educational (professional) relations, interpersonal relations and health and illness according to Rotter - with indexes of finger dermatoglyphics (on the right hand $1-1.19 \%$ of the total number of these indicators, weak direct power); with indexes of palmar dermatoglyphics (on the right hand 9 $6.12 \%$ of the total number of these indicators, of which $2.72 \%$ of the average strength of the straight, $2.72 \%$ of the weak force of the straight and $0.68 \%$ of the weak force of the opposite; on the left hand $12-8.16 \%$ of the total amount of these indicators, of which $4.76 \%$ of the weak force of the straight and $3.40 \%$ of the weak force of the return);

indicators of blue, blue-green, orange-red, light yellow, purple, brown, black and gray colors by Luscher - with indexes of finger dermatoglyphics (on the right hand 8 $8.34 \%$ of the total amount of these indicators, of which $3.13 \%$ of weak power direct and $5.21 \%$ of weak force of the inverse; on the left hand $7-7.29 \%$ of the total number of these indicators, of which $2.08 \%$ of the weak force of the inverse, $1.04 \%$ of the average force of the inverse and 4.17 $\%$ of the weak force of the inverse); with indexes of palmar dermatoglyphics (on the right hand $8-4.76 \%$ of the total number of these indicators, of which $1.19 \%$ of the weak force of the direct and $3.57 \%$ of the weak force of the inverse; on the left hand $5-2.98 \%$ of the total amount of these indicators, all the weak force of the reverse).

\section{References}

[1] Akbarova, S. N. (2018). Dermatogliphics can be as method of behavior genetics. Education Sciences \& Psychology, 50(4), 26-37.

[2] Akbarova, S. N., \& Azimova, G. A. (2014). Psychological dermatoglyphics of drug addicts. Young scientist, 6, 787791.

[3] Badikov, K. N. (2013). Innovations of psychodermatoglyphics. Legal research, 9, 69-80. doi: 10.7256/2305-9699.2013.9.9266

[4] Chekmarova, N., \& Khadzhynov, V. (2010). Finger and palm dermatoglyphics in genetic prediction of psychomotor endowment in men. The sports bulletin of Dnieper, 2, 233238.

[5] Cummins, H. \& Midlo, Ch. (1961). Finger Prints, Palms and Soles. An Introduction to Dermatoglyphics. Philadelphia.

[6] Dubrovina I. V. (1995). Guide practical psychologist: the mental health of children and adolescents in the context of psychological services. Moscow: Academy.

[7] Efremov, I. S., Zoroastrov, O. M., \& Chistikin, A. N. (2014). The dermatoglyphic peculiarities of skin patterns in the subjects convicted for the sexual offence. Sudebno-meditsinskaia ekspertiza, 57(5), 15-17. PMID:25764876

[8] Eliseev, O. P. (2010). Workshop on psychology. St. Petersburg: Pyter.

[9] Gladkova, T. D. (1966). Skin patterns of the hand and foot of monkeys and humans. M.: Science.

[10] Golovei L. A., \& Rybalko E. F. (2002). Workshop on age psychology. St. Petersburg.: Speech.

[11] larovenko, V. V., \& Kitaev, N. N. (2015). On the problems of the development of fingerprinting. Law and politics, (11), 16331641. doi: 10.7256/1811-9018.2015.11.16773
The results obtained allow us to determine the most significant relationships between the indexes of the finger and palmar dermatoglyphics and the characteristics of the personality traits of healthy Ukrainian men.

\section{Conclusions}

1. In the majority of cases, the personality traits and the dermatoglyphic indices of practically healthy men, have single and inverse, mostly weak forces $(r=0.21-0.29$ and $r=-0.21--0.28$, respectively) correlations. A quantitative analysis of the correlations revealed that between the indices of Eysenck and Luscher personality traits and the finger dermatoglyphics, the majority of reliable correlations were inverse, and between Spielberger, Shmishek and Rotter and the dermatoglyphics indice - direct; between the Spielberger and Luscher personality traits and the palmar dermatoglyphics, most reliable relationships are inverse, and between the Eysenck, Shmishek, and Rotter and the dermatoglyphic indices - direct.

2. The multiple nature of the significant correlations is established only between the Luscher gray index and the left hand I, III and IV fingers ridge count, and left fingers I, II, the summary ridge count of both hands, the total left hand ridge count and delta index $(r=-0.23--0.28)$ and between most indicators of the Rotter subjective control scale and the presence of a pattern on the thenar of the corresponding palm (on the right hand $-r=0.31-0.37$ and on the left hand $-r=0.22-0.29)$.

[12] Kiran, K., Rai, K., \& Hegde, A. M. (2010). Dermatoglyphics as a noninvasive diagnostic tool in predicting mental retardation. Journal of International Oral Health, 2(1), 95-100.

[13] Krylov, A. A. (1990). Workshop on Experimental and Applied Psychology. L.: Publishing House of the Leningrad University.

[14] Lu, G. F., Li, S. N., Gao, L. R., Shi, F., Zheng, K. M., \& Huang, Z. C. (2012). Research on Characteristics of Dermatoglyphics of the Depressed Patients. Acta Anthropologica Sinica, 2, 202-206.

[15] Miroshnikov, S. A., Kravets, O. lu., Filippova, M. G., \& Chernov, R. V. (2006). Appendix to the methodological materials of the expert system of individual support "Longitude": description of the additions to the extended version "Longitude+". St. Petersburg.

[16] Oron, I. (2016). Possible Biomarkers for Assessing Deliberate Self-Injury RiskA Study in Dermatoglyphics. Sucidology Online, 7, 31-39.

[17] Raigorodskii, D. la. (2004). Practical psychodiagnostics. Methods and tests. Samara: Publishing House "Bahrah-M".

[18] Rogov, E. I. (1996). Handbook of practical psychologist in education. M.: "Vlados".

[19] Shrivastava, M., Mathur, R. K., Dhaneria, V., Goyal, S., \& Dhaneria, V. (2016). Dermatoglyphic study in bipolar disorder. Indian Journal of Clinical Anatomy and Physiology, 3(2), 243247. doi: 10.5958/2394-2126.2016.00054.2

[20] Solomin, I. L. (2000). On the other side of the Luscher test. Psychological newspaper, 2/53, 43-44.

[21] Vasan, M. D., \& Thakar, B. R. (2019). Predictive Digital Forensic Model to Track Antisocial Behavior Based on Dermatoglyphics. In Computing and Network Sustainability 
(pp. 349-357). Springer, Singapore. https://doi.org/10.1007/ 978-981-13-7150-9_37

[22] Zoroastrov, O. M., Chistikin, A. N., \& Efremov, I. S., (2014).
Dermatoglyphic features of the skin patterns of persons convicted of serious crimes. Bulletin of Forensic Medicine, $3(2), 9-11$.

\section{КОРЕЛЯЦІЇ ПОКАЗНИКІВ ОСОБЛИВОСТЕЙ ОСОБИСТОСТІ 3 ПОКАЗНИКАМИ ПАЛЬЦЕВОЇ ТА ДОЛОННОЇ ДЕРМАТОГЛІФІКИ ПРАКТИЧНО ЗДОРОВИХ УКРАЇНСЬКИХ ЧОЛОВІКІВ \\ Гунас В. $l$.}

Пошуки нових психодерматогліфрічних зв'язків значно підвищать можливості даного методу і прискорять впровадження наукових розробок в повсякденну практику клініцистів, криміналістів, органів дізнання та інших спеціальностей. Мета роботи - встановити особливості зв'язків між показниками пальцевої і долонної дерматогліфіки та показниками особливостей особистості практично здорових українських чоловіків. Із банку даних матеріалів науково-дослідного центру Вінницького національного медичного університету ім. М. І. Пирогова взяті первинні анкети показників особливостей особистості та дематогліфрічні показники 92 практично здорових чоловіків у третьому поколінні мешканців Подільського регіону України. Обробку показників пальцевої і долонної дерматогліфіки проводили за методикою Cummins H. i Midlo Ch. (1961) у викладі Гладкової Т. Д. (1966). Для оцінки показників особливостей особистості визначали властивості темпераменту (за Айзенком), тривожності (за Спілбергером), акцентуйованих рис особистості (за Шмішеком), мотиваційної спрямованості особистості (за Роттером), а також особливостей психоемоційної організації особистості, агресивності, рівня поширення астенічних $i$ депресивних особистісних проявів (за Люшером). Кореляційний аналіз проведено в ліцензійному пакеті "Statistica 6.1" із використанням статистики Пірсона. Встановлено, що між показниками особливостей особистості та дерматоглісрічними показниками практично здорових чоловіків, у більшості випадків, спостерігаються поодинокі прямі та зворотні, переважно слабкої сили (відповідно $r=0,21$ - 0,29 та $r=-0,21$ - -0,28) зв'язки. Множинний характер подібних кореляцій встановлений лише між показником сірого кольору за Люшером та показниками гребінцевого рахунку I, III і IV пальців правої кисті і I та II пальців лівої кисті, сумарним гребінцевим рахунком пальців обох кистей, тотальним гребінцевим рахунком і дельтовим індексом лівої кисті (r= -0,23 - -0,28) та між більшістю показників шкали суб'єктивного контролю за Роттером та наявністю візерунка на тенарі відповідної долоні (на правій кисті - $r=0,31$ - 0,37, а на лівій кисті - r=0,22 - 0,29). Результати кількісного аналізу достовірних кореляцій показали, що між показниками пальцевої дерматогліфіки та показниками особливостей особистості за Айзенком і Люшером більшість зв'язків мають зворотній характер, а з показниками за Спілбергером, Шмішеком і Роттером - прямий; між показниками долонної дерматогліфрікі та показниками особливостей особистості за Спілбергером і Люшером більшість достовірних зв'язків мають зворотній характер, а з показниками за Айзенком, Шмішеком і Роттером - прямий. Результати кореляційного аналізу дозволили визначити найбільш значущі зв'язки між показниками пальцевої $і$ долонної дерматогліфріки та показниками особливостей особистості практично здорових українських чоловіків.

Ключові слова: дерматогліфічні показники, показники особливостей особистості, практично здорові чоловіки, кореляції.

\section{КОРРЕЛЯЦИИ ПОКАЗАТЕЛЕЙ ОСОБЕННОСТЕЙ ЛИЧНОСТИ С ПОКАЗАТЕЛЯМИ ПАЛЬЦЕВОЙ И ЛАДОННОЙ ДЕРМАТОГЛИФИКИ ПРАКТИЧЕСКИ ЗДОРОВЫХ УКРАИНСКИХ МУЖЧИН}

\section{Гунас В. И.}

Поиски новых психодерматоглифических связей значительно повысят возможности данного метода и ускорят внедрение научных разработок в повседневную практику клиницистов, криминалистов, органов дознания и других специальностей. Цель работы - установить особенности связей между показателями пальцевой и ладонной дерматоглифрики и показателями особенностей личности практически здоровых украинских мужчин. Из банка данных материалов научно-исследовательского центра Винницкого национального медицинского университета им. Н. И. Пирогова взятые первичные анкеты показателей особенностей личности и дематоглифические показатели 92 практически здоровых мужчин в третьем поколении жителей Подольского региона Украины. Обработку показателей пальцевой и ладонной дерматоглифики проводили по методике Cummins H. u Midlo Ch. (1961) в изложении Гладковой Т. Д. (1966). Для оценки показателей особенностей личности определяли свойства темперамента (по Айзенку), тревожности (по Спилбергеру), акцентуированных черт личности (по Шмишеку), мотивационной направленности личности (по Роттеру), а также особенностей психоэмоциональной организации личности, агрессивности, уровня распространения астенических и депрессивных личностных проявлений (по Люшеру). Корреляционный анализ проведен в лицензионном пакете "Statistica 6.1" с использованием статистики Пирсона. Установлено, что между показателями особенностей личности и дерматоглифрическими показателями практически здоровых мужчин, в большинстве случаев, наблюдаются единичные прямые и обратные, преимущественно слабой силы (соответственно $r=0,21$ - 0,29 u r=-0,21 - -0,28) связи. Множественный характер подобных корреляций установлен только между показателем серого цвета по Люшеру и показателями гребешкового счёта I, III и IV пальцев правой кисти и I и II пальцев левой кисти, суммарным гребешковым счётом пальцев обеих кистей, тотальным гребешковым счётом и дельтовым индексом левой кисти $(r=-0,23$ - -0,28) и между большинством показателей шкалы субъективного контроля по Роттеру и наличием узора на тенаре соответствующей ладони (на правой кисти - $r=0,31$ - 0,37, а на левой кисти - $r=0,22$ - 0,29). Результаты количественного анализа достоверных корреляций показали, что между показателями пальцевой дерматоглифики и показателями особенностей личности по Айзенку и Люшеру большинство связей имеют обратный характер, а $c$ показателями за Спилбергером, Шмишеком и Роттером - прямой; между показателями ладонной дерматоглифики и показателями особенностей личности по Спилбергеру и Люшеру большинство достоверных связей имеют обратный характер, а с показателями за Айзенком, Шмишеком и Роттером - прямой. Результаты корреляционного анализа позволили определить наиболее значимые связи между показателями пальцевой и ладонной дерматоглифики и показателями особенностей личности практически здоровых украинских мужчин.

Ключевые слова: дерматоглифические показатели, показатели особенностейличности, практически здоровые мужчины, корреляции. 